Article

\title{
From Just War to Nuclear Pacifism: The Evolution of U.S. Christian Thinking about War in the Nuclear Age, 1946-1989
}

\author{
Stephen R. Rock \\ Department of Political Science, Vassar College, Poughkeepsie, NY 12604, USA; strock@vassar.edu
}

Received: 3 May 2018; Accepted: 17 May 2018; Published: 24 May 2018

\begin{abstract}
During the Cold War, two basic schools of thought emerged among U.S. Christian leaders and ethicists concerning the implications of the nuclear revolution for the use of force by the United States. The just war thinkers held that nuclear war could in fact be conducted within the bounds of traditional just war principles, particularly those of discrimination and proportionality. Since nuclear weapons could be used in war, it followed that they could and should be developed and produced for that purpose and for the purpose of deterrence. The nuclear pacifists held that nuclear war could not be conducted within the confines of traditional just war principles. Since by its nature nuclear war could not be moral, there was no reason for the development and production of nuclear weapons, except for the purpose of deterrence. And since nuclear deterrence required one to make threats of nuclear destruction that it would not be moral to carry out, and, moreover, carried unacceptable risks of miscalculation and inadvertent or accidental use of nuclear weapons, deterrence itself could not be justified, except perhaps as a temporary way station on the path to nuclear disarmament. Although the just war thinkers initially held sway, over time they became less dominant. By the middle of the 1980s, the U.S. Catholic Church and most of the largest Mainline Protestant denominations had formally adopted a nuclear pacifist position. This essay chronicles the victory of nuclear pacifism in these churches, explains it as a reaction to the nuclear weapons and doctrine advocated by the just war thinkers, and implemented by the U.S. government and military, as well as other events and trends in American society, and inquires as to whether or not the just war thinkers and nuclear pacifists influenced the course of U.S. policy.
\end{abstract}

Keywords: just war; nuclear pacifism; nuclear weapons; nuclear deterrence

\section{Introduction}

The advent of the atomic age with the U.S. bombings of Hiroshima and Nagasaki, the Soviet Union's explosion of a nuclear device in August 1949, and the subsequent development of much more destructive thermonuclear weapons (H-bombs) occasioned, among Christian leaders and churches in the United States, a reexamination of Christian ideas concerning the moral permissibility of war. Discussion of the implications of nuclear weapons for Christians and for U.S. policy was conducted both within the churches and without. Books, articles in journals such as Commonwealth, America, the Christian Century, Worldview, and Theological Studies, public lectures, and Congressional testimony were some of the forums in which religious leaders articulated their views and responded to one another. As William Au has noted, the Council on Religion and International Affairs (CRIA) contributed significantly to the dialogue among Catholic and Protestant (and Jewish) thinkers, and their counterparts in "the military and policy making communities" (Au 1985, p. 55). The discussion centered around two questions: Primarily, could a nuclear war be just, and if so under what conditions? And, secondarily, was the possession of nuclear weapons for deterrent purposes morally permissible? 
Early in the Cold War, a consensus emerged that the deliberate targeting of cities with nuclear weapons could not be condoned. In 1946, the Calhoun Commission of the Federal Council of Churches (FCC) issued a statement, "Atomic Warfare and the Christian Faith," that condemned the bombings of Hiroshima and Nagasaki as "morally indefensible" (Federal Council of Churches FCC, p. 11). The following year, in "The Ethics of Atomic War," The Catholic Association for International Peace declared that intentionally killing civilians was "simple murder" (Boyer 2012, p. 172). A participant in the 1954 Second Assembly of the recently-formed World Council of Churches (WCC), held in Evanston, Illinois, reported that "All agreed that the Churches must condemn as evil the mass destruction of civilian populations" (Van Kirk 1954, p. 44). But beyond this, there was considerable disagreement. Out of the ferment, two basic views emerged. One, the just war view, held that nuclear war could in fact be conducted within the bounds of just war principles. Since nuclear weapons could be used in war, it followed that they could and should be developed and produced for that purpose and for the purpose of preventing war through deterrence. Indeed, this view held that a credible nuclear war-fighting capability was essential to successful deterrence.

The opposing view, nuclear pacifism, held that nuclear war could not be conducted within the confines of just war principles. Since by its nature nuclear war could not be moral, there was no reason for the development and production of nuclear weapons, except for the purpose of deterrence. And since nuclear deterrence seemed to require one to make threats of nuclear destruction that it would not be moral to carry out, and, moreover, carried non-trivial risks of nuclear war as a result of miscalculation and inadvertent or accidental use of nuclear weapons, deterrence itself could not be justified, except perhaps as a temporary way station on the path to nuclear disarmament.

Within each camp, there was more variation in views than is possible to fully recognize here. Initially, the just war thinkers had the upper hand. But by the mid-1980s, nuclear pacifism had become dominant within the leadership of both the U.S. Catholic Church and major Mainline Protestant denominations. While the shift from just war thinking to nuclear pacifism had significant implications for popular opinion and public discourse in the United States, its impact on U.S. policy was less substantial. In examining the causes and consequences of this shift, it is useful to begin with a brief overview of U.S. Christian thinking about war and peace on the eve of the atomic age.

\section{Christian Pacifism and Just War in the Pre-Nuclear Era}

It will not be surprising to any student of history to learn that most American Protestant theologians and church leaders during the 1930s and early 1940 were pacifists. As scholars have noted, the pacifist tradition dates back to the earliest days of the church. Christian pacifism prior to what John Yoder has called "the Constantinian shift" was a function of a variety of factors, both religious and pragmatic (Yoder 2009, pp. 57-74). Among the former were the life, teachings, and death of Jesus, which seemed to indicate that Christians should practice non-violence. It was also anticipated by very early Christians that the Second Coming of Christ was imminent, which made it possible for them to accept whatever temporary suffering a pacifist stance might entail. Among the latter was the fact that early Christians, being a small, persecuted minority, were seldom, if ever, in a position to use force effectively against Rome or other secular oppressors.

After the fourth century, the just war tradition eclipsed pacifism as mainstream Christian doctrine. Once Christianity became the official religion of the Roman Empire, it seemed necessary to establish rules by which war could (and could not) be morally fought rather than adhering strictly to a path of nonviolence. Most scholars rightly credit Augustine with being the first to lay out in a systematic fashion what these rules might be. Broadly, they fell into two categories: (1) jus ad bellum, which specified the conditions under which resort to war was permissible, and (2) jus in bello, which set forth the rules by which war had to be conducted. Among the former, the most important was just cause, which has been limited by many just war theorists to self-defense. Among the latter, the most important in the nuclear era were the principle of discrimination, which prohibits intentional targeting and killing of non-combatants (sometimes referred to as "civilians"), and the principle of proportionality, which 
prohibits the death and destruction caused by a particular military action from exceeding the military advantage gained therefrom.

The pacifist tradition, of course, never disappeared. After the Reformation, it remained alive particularly within the "historic peace churches" - the Society of Friends (Quakers), the Mennonites, and the Church of the Brethren. It gained strength during the 1920s and 1930s—even within Catholic tradition, with Dorothy Day and the founding of the Catholic Worker. Much of the impetus for pacifism during the interwar period had to do, of course, with the carnage of the First World War, and with the Treaty of Versailles, which to many Americans, including many Christians, seemed not to reflect the objectives for which so many U.S. lives had been sacrificed. Christian pacifism was both a contributor to and a reflection of the isolationist sentiment that guided U.S. foreign policy throughout most of the period between the wars (Yoder 2009, pp. 282-83).

\section{The Just War Thinkers}

The 1930s and early 1940s were, however, not kind to pacifists. Indeed pacifism seemed to be discredited by its association with the failed policy of appeasement. The "peace churches" remained committed to non-violence, but there arose within Mainline Protestant denominations and within the U.S. Catholic Church a call for "Christian Realism." The foremost exponent of this view was Reinhold Niebuhr, the greatest Protestant theologian of the twentieth century. In his earlier years, Niebuhr had been a pacifist, and he never abandoned his fundamentally liberal support for progressive social policies. He did, however, renounce his pacifist views in the face of the events of the 1930s. In his essay, "Why the Christian Church is not Pacifist," and other writings, Niebuhr argued that most versions of pacifism were heresy because they rejected the Christian doctrine of the innate sinfulness of humankind and substituted for it the belief that human beings were good, if not perfectible (Niebuhr 1940, pp. 5-8). Moreover, pacifists, Niebuhr wrote,

are forced to recognize that an ethic of pure non-resistance can have no immediate relevance to any political situation, for in every political situation it is necessary to achieve justice by resisting pride and power. They therefore declare that the ethic of Jesus is not an ethic of non-resistance, but one of non-violent resistance; that it allows one to resist evil provided the resistance does not involve the destruction of life or property.

There is not the slightest support in Scripture for this doctrine of non-violence. (Niebuhr 1940, pp. 9-10)

Niebuhr's objections to pacifism were not only theological, but also practical. Christians needed to recognize that "Justice is basically dependent on a balance of power. Whenever an individual or a group or a nation possesses undue power, and whenever this power is not checked by the possibility of criticizing and resisting it, it grows inordinate" (Niebuhr 1940, p. 26). Although the use of military force was not the only possible means of resistance, it might very well be necessary in some instances. This was, for Niebuhr, true of the fight against Nazi Germany, which was, he argued, a "task which cannot be avoided" (Niebuhr 1940, p. 29).

There is some dispute among scholars as to whether or not Niebuhr should be considered a just war thinker. As Donald Davidson has observed, he did not employ the terminology of the just war tradition, but Davidson nonetheless regards him as being "the first just-war spokesman in the nuclear age" (Davidson 1983, p. 45). Keith Pavlischek contends, by contrast, that "Niebuhr rejected the Christian just war tradition and did so explicitly as part of a polemic against Roman Catholic natural law doctrine" (Pavlischek 2008, p. 54). Below, I shall argue for other reasons that Niebuhr should not be categorized as a just war thinker. Nonetheless, there can be no question that Niebuhr's critique of pacifism and his demand that both theology and foreign policy recognize the realities of a fundamentally Hobbesian world helped lay the foundation for a revival of the just war tradition.

Among U.S. Catholics in the early postwar era, the Jesuit John Courtenay Murray, editor of Theological Studies, was perhaps the most influential just war thinker. In his 1960 volume, We Hold 
These Truths, Murray wrote that it was "clear that our historical moment is not destined to see a moral doctrine of war discarded as unnecessary." Rather, he declared, "War is still the possibility, not to be exercised even by prayer and fasting. The Church does not look immediately to the abolition of war. Her doctrine still seeks to fulfil its triple traditional function: to condemn war as evil, to limit the evils it entails, and to humanize its conduct as far as possible" (Murray 1960, p. 270). Like Niebuhr, Murray believed, "in principle, that force is still the ultima ratio in human affairs, and that its use in extreme circumstances may be morally obligatory" to prevent wrong from being done. "Today," he wrote, "this ultima ratio takes the form of nuclear weapons, whose use remains possible and may prove to be necessary." But, he contended, "the use of nuclear force must be limited, the principle of limitation being the exigencies of legitimate defense against injustice" (Murray 1960, p. 271).

Murray argued that "since limited nuclear war may be a necessity, it must be made a possibility." "To say," he declared, "that the possibility of limited war cannot be created by intelligence and energy, under the direction of a moral imperative, is to succumb to some sort of determinism in human affairs" (Murray 1960, p. 271). Murray recognized that the first step in creating the possibility of limited nuclear war would be to construct "a sort of 'model' of the limited war" (Murray 1960, p. 271). But he declined to speculate in much detail about what such a model might be. That job fell largely to others, and particularly to the Protestant (Methodist) theologian and ethicist, Paul Ramsey.

Ramsey's writings are vast. While War and the Christian Conscience, published in 1961, set forth broadly his thoughts regarding just war in the nuclear age, the most detailed articulation of his views regarding the application of just war doctrine to nuclear warfare and weapons is found in his 1963 essay, "The Limits of Nuclear War: The Do-able and the Un-do-able." Ramsey found himself appalled by the lack of approbation from his fellow Christians that greeted the Kennedy Administration's announcement, in 1962, that it would move away from the policy of "massive retaliation" (the overwhelming use of nuclear weapons against primarily civilian targets in response to a Soviet attack on either Western Europe or the United States) articulated by Secretary of State John Foster Dulles in 1954, to a strategy that was more focused on the targeting of military forces and assets. To Ramsey, this shift in U.S. policy, which continued and developed under different terminology during subsequent administrations, was a welcome recognition of the moral reality that the just war principle of discrimination prohibited the intentional targeting and killing of civilians in time of war. The so-called "doctrine of double effect" might permit non-combatant deaths as unintended by-products of attacks on military targets, but only within the constraints of a second just war principle, that of proportionality (Ramsey 1963).

For Ramsey, as for other just war thinkers of the time, then, all-out nuclear war was not consistent with just war principles of either discrimination and proportionality and was not, therefore, morally permissible. However, he argued, limited counterforce war, with targeting restricted to military assets, could be consistent as long as these and other just war principles were respected. Ramsey articulated a series of policy recommendations that he believed would help to ensure the limitation of warfare if warfare occurred. First, he suggested that the United States should develop greater defensive capacities at the conventional and sub-conventional levels, reducing reliance on nuclear weapons. Second, he advocated a declared no-first-use policy with respect to strategic nuclear weapons. Third, he expressed openness to the possibility of using battlefield or "tactical" nuclear weapons, which were essentially intended to substitute for conventional ones. Fourth, he recommended that the United States retain a considerable nuclear arsenal for the purpose of conducting counterforce strikes against an enemy. Fifth, he argued that there should be "as wide a 'firebreak' as possible" between counterforce and countervalue war, and that there should also be a firebreak between conventional war and tactical nuclear war (Ramsey 1963, pp. 129-38). Finally, Ramsey held that it was still necessary for the United States to maintain the capacity to engage in countervalue (city) strikes because "in the nuclear age city destruction seems to be deterred only by the threat of city destruction in reprisal" (Ramsey 1963, p. 139). 


\section{The Evolution of U.S. Nuclear Doctrine and Weapons}

As chronicled by Freedman, Halperin, Mandelbaum, and others, U.S. nuclear strategy and weapons development during the Cold War evolved along lines largely consistent with Ramsey's recommendations and the just war tradition as he and his colleagues interpreted it. Secretary of Defense Robert McNamara's announcement in 1962 that the U.S. was shifting its emphasis in nuclear targeting from Soviet cities to the country's conventional and nuclear forces set in motion a process that continued throughout the Reagan Administration and the end of the Cold War. In 1974, the Nixon Administration, influenced heavily by Henry Kissinger, the national security advisor and former Harvard professor whose 1957 book, Nuclear Weapons and Foreign Policy made the case for limited nuclear war, adopted the so-called "Schlesinger Doctrine," named for Secretary of State James Schlesinger. As Schlesinger explained to Congress, "Threats against allied forces, to the extent that they could be deterred by the prospect of nuclear retaliation, demand both more limited responses than destroying cities and advanced planning tailored to such lesser responses" (Lackey 1984, p. 67). The doctrine envisioned a variety of new weapons systems, all aimed at counterforce targeting. These included the highly accurate MX intercontinental ballistic missile (ICBM), the also highly accurate (and survivable) Trident II, D-5 submarine-launched ballistic missile (SLBM), the cruise missile, and the penetrating bomber, the B-1 (Lackey 1984, p. 67). None of these systems was deployed during the Nixon Administration, but all eventually became part of the U.S. nuclear arsenal.

Toward the end of the 1970s, the administration of Jimmy Carter announced what it termed the "countervailing strategy." Formally articulated in Presidential Directive No. 59 (PD-59), the countervailing strategy, as explained by the undersecretary of defense for policy planning, Walter Slocombe, required that the United States "must have a doctrine and plans for the use of our forces (if they are needed) that make clear to the Soviets the hard reality that, by any course leading to nuclear war and in any course a nuclear war might take, they could never gain anything amounting to victory on any plausible definition of victory, or gain an advantage that would outweigh the unacceptable price they would have to pay" (Slocombe 1981, p. 18). Toward this end, the U.S. military would push forward with the new weapons systems envisaged by the Nixon Administration.

The discussion to this point has focused on strategic nuclear weapons and policy. It is important to recognize that there were ongoing efforts to develop and deploy theater and tactical nuclear weapons as well. Such weapons, which had a relatively short range and lesser payload (and yield) than strategic systems, were intended for use on the battlefield as an adjunct to, or as a substitute for, conventional weapons such as bombs and artillery shells. Although tactical nuclear weapons had been deployed among NATO forces since the 1950s, and were eventually deployed in Asia as well, one such weapon became the source of considerable controversy in the late 1970s. This was the enhanced radiation weapon (ERW), popularly known as the "neutron bomb." Rather than destroying by blast and heat, the ERW was designed to emit intense radiation, killing enemy soldiers (and any other living things) within its range. There was a logic to the warhead. By leaving infrastructure (roads, bridges, buildings) intact, it would be easier for American ground forces to advance against the enemy once it had been detonated. Nonetheless, the anticipated deployment of the ERW in Europe provoked such a furor in both Europe (where the weapon would have been detonated), and the United States that the Carter Administration was forced to abandon its plans. Many felt that a weapon that was intended to kill human beings while leaving inanimate objects undisturbed could not possibly be moral. Others, as we shall see, viewed the deployment of the warhead (and tactical nuclear weapons more generally) as breaching the firewall between the use of conventional weapons on the one hand and nuclear weapons on the other.

The Reagan Administration represented in many respects the culmination of prior administrations' efforts to develop a nuclear war-fighting, war-winning capability and doctrine. But it went much further. For the first time, the U.S. government officially announced its intentions to plan for a protracted, though in principle limited, nuclear war. Of particular note was the administration's emphasis on decapitation, an attack on the Soviet Union's (or other enemy's) leadership and its 
command and control capabilities, intended to render an effective, coherent response as difficult as possible (Halloran 1982). The Reagan Administration pushed forward vigorously on strategic weapons systems already under development: the MX missile (named the "Peacekeeper"), the B-1 bomber (which had been canceled by the Carter Administration), and the Trident II, D-5 SLBM. At the theater-level, it introduced a new intermediate-range ballistic missile (IRBM), the Pershing II. It also moved ahead with plans to deploy an ERW in Europe.

Perhaps the most important and ultimately most controversial undertaking by the Reagan Administration was the Strategic Defense Initiative (SDI), which critics promptly dubbed "Star Wars," after the blockbuster film that had been released several years before. SDI envisioned an area (or national, as opposed to "point") defense of U.S. territory employing multiple layers of ground-based, air-based, and space-based systems. Its stated purpose was to defend the American population from a Soviet nuclear attack. Indeed, Reagan and his advisers argued that SDI would render nuclear weapons "impotent and obsolete," thus paving the way for eventual disarmament (Reagan 1983a).

Aside from questions about the technical feasibility and expense of SDI, critics of the program, including, as we shall see, many churches, expressed concerns that it might undermine stability at the strategic nuclear level. Despite all efforts by the just war thinkers and the U.S. military, deterrence, as Ramsey had suggested, might still require the capacity to destroy cities on both sides. It was precisely to maintain this condition of mutual assured destruction (MAD) that the 1972 Anti-Ballistic Missile (ABM) Treaty had been concluded. The ABM Treaty prohibited the construction of national missile defense (NMD) systems, allowing only so-called "point defenses" intended to protect ICBMs from attack. Hence, building SDI was going to require the abrogation or modification of one of the most important and highly-valued arms control agreements of the Cold War. Moreover, in practical terms, critics believed the system would, if it could be made to work, potentially allow the United States to launch a first strike against Soviet strategic weapons and then hide behind its anti-missile shield (Boffey 1985).

There is no evidence that the Reagan Administration ever contemplated launching such a first strike. But it was not, at the time, difficult to imagine. The anti-Soviet rhetoric from the administration far surpassed that of recent prior administrations. In remarks to the National Association of Evangelicals (NAE), Reagan identified the Soviet Union as the "focus of evil in the modern world" and subsequently referred to it as "the evil empire" (Reagan 1983b). More broadly, the administration declared a policy of "rollback" - of rolling back or reversing the spread of communism, uprooting it from places in which it had become established. This was, at least in terms of language, a dramatic departure from the "containment" policies of previous administrations. Finally, as a reaction (or antidote) to the Carter Administration's allegedly feeble foreign policy and the so-called Vietnam Syndrome, the Reagan Administration adopted a much more muscular approach in foreign affairs, as reflected in the invasion of Grenada, the covert war against the Sandinista government of Nicaragua, and other wars against leftist insurgencies elsewhere in Central America.

\section{The Rise of Nuclear Pacifism}

Against this background, it is easy to understand the rise of nuclear pacifism among religious leaders and in the churches as a reaction to developments in U.S. nuclear weapons and doctrine, as well as the rhetoric and foreign policy of the Reagan Administration. And it was certainly that. But it was not only that. The Vietnam War had had a particularly profound effect on American society. The long, bloody (especially on the communist side) conflict, which had ended first inconclusively and then ultimately in American and South Vietnamese defeat, raised serious questions about both the morality and efficacy of the U.S. use of force. Beginning in the late 1950s, left-leaning scholars of the so-called revisionist school of U.S. foreign policy argued that the United States was no less imperialist (and perhaps moreso) than the Soviet Union and its communist allies. The perception grew, perhaps out of the fact that the superpowers had coexisted for roughly thirty years and that containment seemed to 
be largely working, that the real danger to U.S. security was not the Soviet Union and the inexorable march of communism, but nuclear war and thus the weapons themselves.

Within the U.S. Catholic Church, specifically, two factors helped shape developments. One was the emergence of Pax Christi in the early 1970s as a new and vital pacifist voice. More important, perhaps, was the appointment of younger, more progressive bishops to positions in the U.S. Catholic hierarchy. Sometimes labeled the "Jadot bishops," after Belgian Archbishop Jean Jadot, the Vatican's apostolic delegate to the United States from 1973 to 1980, the new bishops brought energy, concern for social justice issues, and a heightened emphasis on the pastoral responsibilities of the Church.

Outside the churches (and within), anti-war activists and civil-rights activists revived the tradition of pacifism and theories of non-violent resistance, which had seemed so thoroughly discredited several decades before. Among the most influential in the scholarly community was Gene Sharp, whose work drew inspiration from Gandhi, and who, in 1986, published a book, Making Europe Unconquerable, in which he argued that the United States and its allies could defeat and, he believed, deter a Soviet invasion of Western Europe by elaborate planning for civilian-based, non-violent resistance that would render Soviet conquest so unprofitable that Kremlin leaders would not seek to undertake it.

To these influences must be added at least two factors, the first of which was the emerging scientific research on the possible climatic effects of a nuclear exchange. In the so-called "nuclear winter" hypothesis, popularized by the well-known Cornell astronomer Carl Sagan in the early 1980s, researchers argued that a significant number of nuclear strikes, especially if directed at urban areas, would produce so much dust, smoke, and soot that the sun's rays would be considerably diminished, resulting in sudden and potentially long-term atmospheric cooling. Wrote Sagan and his colleagues, "When combined with the prompt destruction from nuclear blast, fires, and fallout and the later enhancement of solar ultraviolet radiation due to ozone depletion, long-term exposure to cold, dark, and radioactivity could pose a serious threat to human survivors and to other species ... The possibility of the extinction of Homo sapiens cannot be excluded" (Francis 2017).

Developments in American society and culture also played a role. In late 1979, the young defense analyst and activist Randall Forsberg called for an end to the development, testing, and deployment of nuclear weapons by the Soviet Union and the United States. With the publication of her "Call to Halt the Nuclear Arms Race," issued the following year, the nuclear freeze movement rapidly gained momentum. In 1982, upwards of a million Americans marched in New York City in support of the freeze. 1982 also saw the publication by Jonathan Schell of The Fate of the Earth (a compendium of essays previously published in the New Yorker), which sought to describe the consequences of a nuclear war. These consequences were graphically depicted in the 1983 televised film, The Day After, which suggested that a nuclear war might result in the demise of human society as it had been known. The initial airing of this much-hyped movie was viewed by an estimated 100 million Americans and remains to this day the highest rated televised film in history. As Hank Stuever wrote in the Washington Post several years ago, the impact on himself and other viewers of The Day After was "profound." "Most of all," he noted with respect to nuclear war, "we understood that when (not if) it happened there was no such thing as survival" (Stuever 2016).

There can be no doubt that Christian leaders and churches in the United States were aware of all of these factors, which converged in the late 1970s and early 1980s, and that they were influenced by them. But it should not be supposed that nuclear pacifism arose suddenly at this point in time. Although Paul Boyer has noted that there was a substantial drop-off in anti-nuclear activism within American society between roughly 1963 and 1980, dialogue among religious leaders and, increasingly, within church hierarchies had continued (Boyer 1984). The participants in this dialogue included Ramsey and other just war theorists such as Michael Novak (a Catholic), Michael Walzer (of Jewish descent) and, later, James Turner Johnson (Catholic), as well as pacifists such as Gordon Zahn (Catholic), Stanley Hauerwas (born a Methodist, but largely ecumenical in his writing), and John Howard Yoder (a Mennonite). Debate within the U.S. Catholic Church, which has been admirably chronicled by both Jim Castelli and William Au, was perhaps the most vigorous (Au 1985; Castelli 1983). 
The origins of nuclear pacifism within the Catholic Church date to the early 1960s. Shortly after the opening of the Second Vatican Council (Vatican II) in 1962, Pope John XXIII had issued his famous encyclical, Pacem in Terris (Peace on Earth). The pope understood the logic of nuclear deterrence, but he lamented the fact that human beings all over the earth were forced to live in "constant fear" that nuclear war, with "the appalling destruction and sorrow" that would follow, might erupt "by some unexpected and unpremeditated event." He concluded on the subject:

Justice, then, right reason and consideration for human dignity and life urgently demand that the arms race should cease; that the stockpiles which exist in various countries should be reduced equally and simultaneously by the parties concerned; that nuclear weapons should be banned; and finally that all come to an agreement on a fitting program of disarmament, employing mutual and effective controls. (Pope John 1963, sct. 112)

Pacem in Terris was followed, in 1965, by the conciliar document, Gaudium et Spes (Pastoral Constitution on the Church in the Modern World) promulgated by John XXIII's successor, Pope Paul VI. After noting that "war has not been rooted out of human affairs," Gaudium et Spes went on to state:

The horror and perversity of war is immensely magnified by the addition of scientific weapons. For acts of war involving these weapons can inflict massive and indiscriminate destruction, thus going far beyond the bounds of legitimate defense. Indeed, if the kind of instruments which can now be found in the armories of the great nations were to be employed to their fullest, an almost total and altogether reciprocal slaughter of each side by the other would follow, not to mention the widespread devastation that would take place in the world and the deadly after effects that would be spawned by the use of weapons of this kind.

All these considerations compel us to undertake an evaluation of war with an entirely new attitude. (Pope Paul 1965, scts. 79-80)

\section{The Triumph of Nuclear Pacifism}

The call of Vatican II to evaluate war with "an entirely new attitude" was taken up in the United States by the National Conference of Catholic Bishops (NCCB). In 1980, the Bishops appointed a committee to draft a letter outlining their views; this work was done principally by J. Bryan Hehir, their chief technical adviser on foreign policy and a prominent contributor, himself, to the debate over nuclear weapons and nuclear war both within and outside the Church. Bruce Russett, a political scientist and nuclear strategist from Yale University, also served as a consultant. The process involved extensive hearings with many expert witnesses from the government, the military, and the academy; three drafts, which encountered stiff resistance from both just war thinkers (who thought nuclear pacifism was unrealistic) and pacifists (who thought nuclear pacifism did not go far enough); conversations with Reagan Administration officials; and consultation with the Vatican (McBrady 2015). In the end, the Bishops approved, by a vote of 238 to 9-a remarkable margin given the vigor of the debate-the single most important document to emerge from a U.S. Christian church during the 1980s: The Challenge of Peace: God's Promise and Our Response (Castelli 1983, p. 177).

The Challenge of Peace, which was published in May 1983, undertook, to the consternation of just war thinkers including George Weigel and William O'Brien, to evaluate war with an "entirely new attitude." Weigel objected especially to what he viewed as the "abandonment of the classic Catholic heritage" of tranquillitas ordinis ("peace as order within political community"), but he found "manifold flaws" in the document and regarded it as "a tragically lost opportunity" (Weigel 1987, pp. 31, 280, 285). After elevating the Church's tradition of pacifism to a level at which it enjoyed nearly co-equal status with the just war tradition and stating that "Catholic teaching begins in every case with a presumption against war" (National Conference of Catholic Bishops NCCB, p. iii), the Catholic Bishops took direct aim at the arguments of the just war thinkers. In doing so, it is important to note, the NCCB, like other 
denominational bodies that subsequently published their own manifestoes, employed the principles of the just war tradition, especially the principles of discrimination and proportionality, to arrive at very different conclusions.

To the claim that nuclear war could be limited in a meaningful way, the Catholic Bishops wrote, "Today, the possibilities of placing moral and political limits on nuclear war are so minimal that the moral task is prevention: as a people, we must refuse to legitimate the idea of nuclear war" (National Conference of Catholic Bishops NCCB, para. 131); With respect to counterforce targeting, they quoted the findings of a study conducted by the Pontifical Academy of Sciences:

Even a nuclear attack directed only at military facilities would be devastating to the country as a whole. This is because military facilities are widespread rather than concentrated at only a few points. Thus, many nuclear weapons would be exploded. Furthermore, the spread of radiation due to the natural winds and atmospheric mixing would kill vast numbers of people and contaminate large areas. The medical facilities of any nation would be inadequate to care for the survivors. An objective examination of the medical situation that would follow a nuclear war leads to but one conclusion: prevention is our only recourse. (National Conference of Catholic Bishops NCCB, para. 145)

Beyond their rejection of strategic counterforce (as well as countervalue) targeting, the Bishops were critical of tactical nuclear weapons, arguing that they would break down the firewall between conventional and nuclear war. Use of such weapons, they declared, would produce a "danger of escalation [to strategic nuclear war] so great that it would be morally unjustifiable to initiate nuclear war in any form" (National Conference of Catholic Bishops NCCB, para. 152).

With the prevention of nuclear war as its goal, the NCCB then turned its attention to how such war might be prevented and specifically to the topic of deterrence. Here again, the Challenge of Peace took a position largely at odds with the just war thinkers. Noting that, "For some, the fact that nuclear weapons have not been used since 1945 means that deterrence has worked" (National Conference of Catholic Bishops NCCB, para. 169), the Bishops declined to embrace it as a long-term strategy. While they acknowledged that war-fighting capabilities might "enhance the credibility of the deterrent, particularly the strategy of extended deterrence," they argued that in fact such capabilities would "threaten the viability of other nations' retaliatory forces, making deterrence unstable in a crisis and war more likely" (National Conference of Catholic Bishops NCCB, para. 184, emphasis mine).

It seems clear that the Bishops would have liked to declare outright that nuclear deterrence was immoral, but they found themselves unable to so. Instead, recognizing the reality of a nuclear world in the very short term, they adopted a "strictly conditioned moral acceptance" of the strategy (National Conference of Catholic Bishops NCCB, para. 186). The principal condition of their acceptance was that "Nuclear deterrence should be used as a step on the way to progressive disarmament" (National Conference of Catholic Bishops NCCB, para. 188) Recognizing that "Progress toward a world free of dependence on nuclear deterrence must be carefully carried out," the Bishops nonetheless stated that "it must not be delayed," citing "an urgent moral and political responsibility to use the 'peace of a sort' we have as a framework to move toward authentic peace through nuclear arms control, reductions, and disarmament" (National Conference of Catholic Bishops NCCB, para. 189).

Ramsey had previously argued that it would not be moral to intend to do what it would be immoral to do, and he had suggested that bluffing might be a way of maintaining deterrence without the need for murderous intent (Ramsey 1963, p. 47). By contrast, on the question of whether or not it could be morally permissible to threaten, even in the very short term, what it would not be morally permissible to do, the Bishops, as O'Brien complained, side-stepped, leaving the answer "shrouded in 'a centimeter of ambiguity'" (O'Brien 1984, p. 170). At the policy level, the NCCB recommended an immediate and complete ban on nuclear testing, deep reductions in the U.S. and Soviet nuclear arsenals, removal of short-range (tactical and theater) nuclear weapons from those arsenals, and a variety of other measures (National Conference of Catholic Bishops NCCB, para. 191) The Bishops were careful 
to remind their readers that their "lack of an unequivocal condemnation of deterrence is meant only to be an attempt to acknowledge the role attributed to deterrence, but not to support its extension beyond the limited purpose discussed above" (National Conference of Catholic Bishops NCCB, para. 192).

Finally, the U.S. Catholic Bishops, following the lead of Gene Sharp, suggested that non-violent, civilian-based resistance should be given much greater attention as an alternative to nuclear defenses. Recognizing that such resistance "may not always succeed," they wrote, "before the possibility is dismissed as impractical or unrealistic, we urge that it be measured against the almost certain effects of a major war" (National Conference of Catholic Bishops NCCB, para. 223).

Within a short time following publication of the Challenge of Peace, Mainline Protestant churches in the United States published their own documents concerning nuclear weapons, war, and deterrence. In 1985, the Fifteenth Synod of the United Church of Christ (UCC) declared the UCC to be a "just peace church." Consistent with the Catholic Bishops' position, the synod concluded that "Just War criteria itself [sic] now rules out war under modern conditions." Therefore, they argued, it was "imperative to move beyond Just War thinking to the Theology of a Just Peace." The UCC, also drawing on the tradition of Christian pacifism, was more optimistic than were the just war thinkers about the possibility of peace and the promise of non-violence as a strategy of resistance. With regard to the latter, the synod stated, "Nonviolence is a Christian response to conflict shown to us by Jesus. We have barely begun to explore this little known process of reconciliation" (United Church of Christ UCC). The Church expressed its "opposition to all weapons of mass destruction," calling on the countries of the world to "declare that they will never use such weapons ... cease immediately the testing, production, and deployment of nuclear weapons ... begin dismantling these arsenals, and ... while the process of dismantling is going on, negotiate comprehensive treaties banning all such future weapons by any nation" (United Church of Christ UCC). The UCC explicitly rejected "any use or threat to use weapons and forces of mass destruction and any doctrine of deterrence based primarily on using such weapons" (United Church of Christ UCC, emphasis mine). However, the UCC also rejected unilateral disarmament, implicitly recognizing that nuclear deterrence might be necessary (and thus morally permissible) for at least a time.

The UCC's Just Peace Pronouncement was followed shortly thereafter by documents issued by the United Methodist Church (UMC), the Episcopal Church, and the Presbyterian Church (USA), among others. Of these, the UMC document, In Defense of Creation: The Nuclear Crisis and a Just Peace, was perhaps the most substantive, roughly matching in length the Challenge of Peace. As the latter had been subjected to withering criticism by Weigel and $\mathrm{O}^{\prime}$ Brien, so the former received a book-length rebuttal authored by John Ramsey and containing an epilogue by Stanley Hauerwas (Ramsey 1988). It is beyond the scope of this essay to engage the substance of their critiques, but they are evidence that In Defense of Creation was not greeted enthusiastically by either just war thinkers or certain pacifists.

This is not surprising, given that the Methodist Bishops wrote early in their treatise that "the nuclear crisis poses fundamental questions of faith that neither the pacifist nor the just-war traditions have adequately addressed" (United Methodist Church UMC, p. 13). With respect to the just war tradition, the UMC cited three just war principles that it believed would almost inevitably be violated in a nuclear war. The first of these was "a reasonable hope of success" in such a war, directly challenging the just war thinkers who claimed that meaningful victory or some other positive outcome was possible. The second and third were the principle of discrimination and the principle of proportionality, which the Catholic Bishops had previously identified as critical. Expressing the same concerns about escalation as their Catholic counterparts, the Methodist Bishops wrote that it was unlikely that "any resort to nuclear weapons by major powers can result in a strictly controlled or 'limited' nuclear war" (United Methodist Church UMC, p. 13). "These considerations," they declared, "compel us to say No, a clear and unconditioned No, to nuclear war and to any use of nuclear weapons" (United Methodist Church UMC, p. 13). In particularly pointed language, the Bishops suggested that those who disagreed were guilty of what they termed "nuclear idolatry that presumes to usurp the sovereignty of the God of shalom over all nations and peoples" (United Methodist Church UMC, p. 13). 
With respect to nuclear deterrence, the Methodist Bishops, like their counterparts in most other denominations, rejected it, noting that over the long term, peace through deterrence presumed a level of rationality on the part of military and government leaders that was unlikely to hold because of the psychological and emotional tensions produced by the nuclear stand-off. The "fundamental flaw at the very core of deterrence doctrine," they wrote, is "a contradiction between inordinate confidence in the rationality of decision makers and the absolute terror of annihilation. Nothing in our understanding of fallible and fallen human nature warrants the expectation that this relentless strain between reason and terror can endure indefinitely" (United Methodist Church UMC, p. 48). Deterrence would eventually fail, and the consequences would be catastrophic. At this point, however, like the Catholic Bishops and the UCC, the Methodist Bishops were forced to recognize the reality that vast nuclear arsenals existed and that they would not and could not be immediately abandoned. Revealing their difficulty in articulating a coherent position, the Bishops simultaneously declared that "Deterrence must no longer receive the churches' blessing, even as a temporary warrant for the maintenance of nuclear weapons," and that "The interim possession of such weapons for a strictly limited time" could be justified by what they termed "an ethic of reciprocity as nuclear-weapon states act together in agreed stages to reduce and ultimately to eliminate their nuclear weapons" (United Methodist Church UMC, p. 48).

The Methodist Bishops' grudging acceptance of nuclear deterrence, with its ultimate reliance on MAD, helps to explain why they dismissed the notion that the Reagan Administration's proposed Strategic Defense Initiative provided a way out of the nuclear dilemma. In addition to citing the technical obstacles to the construction of such a system, the "holes" in it (it would not be effective against cruise missiles or other low-flying weapons), the potentially prohibitive costs, and the necessity of abrogating or at least amending the ABM Treaty, the Bishops expressed the view that if a successful NMD system could be built, it would actually increase the likelihood of war. In words that echoed those of anti-SDI activists and scholars outside the churches, they wrote that "if SDI should seem to promise a perfect shield, this 'defense' would have provocative offensive implications, no matter what US leaders say about their intentions. A foolproof defense would indeed make an adversary's deterrent forces 'impotent' thus heightening insecurity and raising fears of a possible US first strike - a pre-emptive attack with military impunity" (United Methodist Church UMC, pp. 50-51). Rather than causing Soviet leaders to abandon their nuclear weapons, as the Reagan Administration suggested would occur, the Bishops thought it more likely that SDI would provoke a new and more vigorous offensive arms race. They were fearful that Soviet leaders might "become tempted to consider launching their own pre-emptive strike before their deterrent forces are disarmed by US 'defenses'" (United Methodist Church UMC, p. 51). Indeed, they worried that "A discovery of that Soviet desperation by US decision makers could well prompt them to make a pre-pre-emptive strike on the Soviet Union" (United Methodist Church UMC, p. 51). No policy maker or scholar could have written a more concise treatment of the potentially negative implications of SDI for the stability of nuclear deterrence.

In 1987, the Commission on Peace of the Washington Diocese of the Episcopal Church issued The Nuclear Dilemma: A Christian Search for Understanding. The year thereafter, the Presbyterian Church (USA) produced Christian Obedience in a Nuclear Age. In its document, the Episcopal Commission reiterated many of the themes of other denominations. The authors doubted the possibility of limited nuclear war, citing a number of "delusions" they ascribed to just war thinkers. These included the assumption that military targets and civilian targets could be separated from one another, the assumption that command and control functions would remain effective throughout a nuclear exchange, and the notion that effective "firebreaks" could be constructed among categories or uses of weapons (Episcopal Church. Diocese of Washington, Commission on Peace 1987, p. 48). Forcefully, they rejected the views espoused by Ramsey (whom they named), finding themselves "especially disturbed by the argument that counterforce targeting is 'more moral' than targeting cities," given the fact that military installations were often located in close proximity to population centers and the likelihood that destruction of command and control facilities would make the meaningful limitation of war impossible. To the doctrine of double effect, which would allow the unintentional killing 
of civilians as a result of striking military targets, they responded that there was no measurable distance between something being intended and something being foreseen: "If one knows that terrible and long-lasting destruction will occur unavoidably, and accepts that, then 'unintendedness' has no meaning" (Episcopal Church. Diocese of Washington, Commission on Peace 1987, p. 108).

Ultimately, the writers of The Nuclear Dilemma judged that nuclear war would almost inevitably run afoul of the just war principles of both discrimination and proportionality. For reasons similar to those of the Methodist Bishops, they did not see SDI as a means of escaping the dilemma of deterrence. They did acknowledge that some supporters of the program regarded it as a means of enhancing deterrence by protecting the U.S. second-strike retaliatory capability and conceded that this had become "'the acceptable goal of SDI for most nuclear strategists" (Episcopal Church. Diocese of Washington, Commission on Peace 1987, p. 60). In the end, however, they concluded that

SDI offers no prospect of achieving any of the visions that have given it momentum. We are extremely skeptical that it can ever create a shield to protect populations. It offers little prospect of substituting a defensive strategy for deterrence. And whether the stated aim is to shield populations or to enhance deterrence, the pursuit of SDI will inevitably trigger a dangerous new arms race in space, which will destabilize the nuclear balance. (Episcopal Church. Diocese of Washington, Commission on Peace 1987, p. 61)

The Episcopal Commission called, as a practical matter, for deep reductions in the U.S. and Soviet nuclear arsenals, keeping any SDI program strictly within the bounds of the ABM Treaty, a comprehensive ban on the testing of nuclear weapons, and the "destruction of obsolete tactical nuclear weapons", among other measures (Episcopal Church. Diocese of Washington, Commission on Peace 1987, pp. 19, 101).

On the issue of nuclear deterrence, the Episcopal Commission hewed less to a nuclear pacifist position than either the U.S. Catholic or Methodist Bishops. Acknowledging that "complete abolition" of nuclear weapons was "a future hope and not a present possibility", the Commission stated what the other churches could not bring themselves to say: that there was "a continuing need for credible deterrence" (Episcopal Church. Diocese of Washington, Commission on Peace 1987, p. 46). While they recognized that deterrence might fail for various reasons, with catastrophic consequences, the writers proclaimed that they found it "morally acceptable to possess nuclear weapons for the purpose of deterrence, understanding the implicit and uncertain dangers that they may be used. We take this view", they stated, "because we see no other acceptable way to reduce the likelihood of nuclear war at this time" (Episcopal Church. Diocese of Washington, Commission on Peace 1987, p. 113). Importantly, in terms of the moral argument, the Episcopal Commission contended that deterrence was less a strategy than a situation. It suggested that successful deterrence did not depend on or require the intention to use nuclear weapons in any particular ways, but on the simple fact of their existence, echoing the view of "existential deterrence" theorists in the scholarly and policy making communities, some of whom had been consulted in the process of the Commission's deliberations (Episcopal Church. Diocese of Washington, Commission on Peace 1987, p. 110). The Commission thus extricated itself from the difficult question, which seemed either to bedevil or be ignored by other denominations, of whether or not it was morally permissible to threaten (or intend) an action that it would be immoral to carry out.

Christian Obedience in a Nuclear Age, published in 1988, repeated many of the themes found in the documents of other Christian denominations. On the matter of nuclear war, the Presbyterian Church noted that "several overtures from individual presbyteries asked whether or not the criteria of the just war doctrine are applicable to war in the nuclear age". In Christian Obedience, it responded, "We believe that they are. It is precisely on the basis of the just war doctrine that participation in nuclear war must be condemned. Such criteria as 'proportionality' (that the costs in life and property of engaging in war are in reasonable proportion to the good that is to be achieved) or 'discrimination' (that civilian, noncombatant targets are to be spared) cannot be met when nuclear weapons are used" (Presbyterian Church USA, p. 5). 
The 1971 General Assembly of the Presbyterian Church had, well before the U.S. Catholic Bishops, found nuclear deterrence morally defensible only if "the sole purpose of nuclear deterrence is to buy a little time to work for peaceful alternatives" (Presbyterian Church USA, p. 27). The 1988 General Assembly expressed its agreement with the Methodist Bishops that a deterrence strategy for purposes other than as an "interim measure of self-defense" could not be condoned (Presbyterian Church USA, p. 27). The 1988 Assembly exhorted

all Presbyterians as well as the governing bodies and agencies of the Presbyterian Church (U.S.A.) to advocate with renewed vigor realistic negotiations with the Soviet Union for steps which will enable the nations to move away from nuclear deterrence and the militarization of space by reaching agreement on a "freeze" on the production and deployment of nuclear weapons; a comprehensive test ban; a mutual "no first use" pledge; phased, mutual, verifiable reduction of nuclear arsenals and the eventual elimination of all nuclear weapons; demilitarization of space; strengthening of existing nonproliferation treaties; and negotiated ends to regional conflicts. (Presbyterian Church USA, p. 28)

Like the Catholic Bishops and the Episcopal Church in particular, the Presbyterian Church saw promise in "nonviolent, civilian-based defense as an alternative to nuclear deterrence," and the General Assembly instructed "the appropriate ministry unit of the General Assembly Council to provide on request to congregations and presbyteries a bibliography" of materials regarding this strategy (Presbyterian Church USA, p. 28).

\section{Just War Thinkers vs. Nuclear Pacifists: Summarizing the Debate}

It seems useful at this point to summarize the major points of agreement and disagreement between the just war thinkers and the nuclear pacifists. There were really only three points of agreement between the two groups. The first was that traditional just war principles could and should be applied to war in the nuclear age. The second was the moral unacceptability of attacks on cities as population centers. The third was that unilateral disarmament by the United States was not a solution to the nuclear dilemma.

Beyond this, common ground was scarce. The groups differed on whether or not significant counterforce targeting would inevitably violate the just war principles of discrimination and proportionality. They made divergent assumptions regarding whether or not escalation could be controlled and a nuclear war be kept limited. As a result, they disagreed as to the utility and risks associated with certain weapons systems, for example, tactical nuclear weapons. They had somewhat different understandings of whether or not nuclear war was likely to erupt as the result of a conscious, rational decision-making process or as a consequence of misunderstanding, inadvertence, or accident. They disagreed on whether or not multilateral nuclear disarmament was really feasible, as well as whether or not non-violent resistance might provide a realistic alternative to deterrence. As a consequence, they came to very different conclusions regarding the morality of both the use of nuclear weapons and the strategy of nuclear deterrence. Table 1 provides a summary of the main points of agreement and disagreement between the just war thinkers on the one hand and the nuclear pacifists on the other.

Most of the assumptions made by the two groups have not been tested in the years since Hiroshima and Nagasaki, and so it is difficult to assess their merits. Two things, however, can be said. First, as discussed in the following section, the nuclear pacifists were too optimistic in their views regarding the ease and rapidity with which multilateral nuclear disarmament could be accomplished. Second, as Alexander Downes has shown, during the pre-nuclear era governments and militaries often ignored the moral proscription against deliberately targeting civilian populations, usually when their military positions became precarious or in order to achieve victory at the lowest possible cost to themselves (Downes 2008). A recent study by Scott Sagan and Benjamin Valentino found that "The majority of the U.S. public has not internalized either a belief in the nuclear taboo or a strong noncombatant immunity 
norm" (Sagan and Valentino 2017). These findings call into question the assumption of the just war thinkers that a nuclear war could and would be fought with limited, counterforce strikes.

Table 1. Just War Thinkers and Nuclear Pacifists: A Summary.

\begin{tabular}{|c|c|c|}
\hline & Just War Thinkers & Nuclear Pacifists \\
\hline $\begin{array}{l}\text { Just war criteria appropriate } \\
\text { for evaluating nuclear war? }\end{array}$ & Yes & Yes \\
\hline $\begin{array}{l}\text { Attacks on population centers } \\
\text { or all-out war permissible? }\end{array}$ & No & No \\
\hline $\begin{array}{l}\text { Unilateral disarmament a } \\
\text { viable option? }\end{array}$ & No & No \\
\hline $\begin{array}{l}\text { Counterforce targeting } \\
\text { permissible? }\end{array}$ & Yes, even obligatory & No \\
\hline $\begin{array}{l}\text { Limited nuclear war (control } \\
\text { of escalation) possible? }\end{array}$ & Yes & Unlikely \\
\hline $\begin{array}{l}\text { Nuclear deterrence } \\
\text { permissible? }\end{array}$ & Yes, perhaps even obligatory & $\begin{array}{l}\text { Only in the short term, until mutual } \\
\text { disarmament occurs }\end{array}$ \\
\hline Tactical nuclear weapons & Useful in war-fighting & $\begin{array}{l}\text { Dangerous because of the likelihood of } \\
\text { escalation to the strategic nuclear level }\end{array}$ \\
\hline $\begin{array}{l}\text { Non-violent resistance as an } \\
\text { alternative to nuclear } \\
\text { deterrence }\end{array}$ & $\begin{array}{l}\text { Not viable; equivalent to } \\
\text { surrender }\end{array}$ & Potentially viable; worth exploring \\
\hline $\begin{array}{l}\text { Multilateral nuclear } \\
\text { disarmament feasible? }\end{array}$ & No & Yes \\
\hline $\begin{array}{l}\text { Risk of nuclear war as a result } \\
\text { of misunderstanding, } \\
\text { inadvertence, or accident }\end{array}$ & Low & Relatively high \\
\hline
\end{tabular}

Although Reinhold Niebuhr is widely regarded as being responsible for the revival of just war thinking in the nuclear age, on most issues he would have sided with the nuclear pacifists. While he believed that nuclear weapons and the threat to use them could not be abandoned, Niebuhr regarded the situation as "tragic" and warned that actual use of the weapons might result "in a world in which it would be better not to be alive" (Niebuhr 1952, pp. 1, 39). "No one," he wrote, "can be sure that a war won by the use of the modern means of mass destruction would leave enough physical and social substance to rebuild a civilization among either victors or vanquished" (Niebuhr 1952, p. 2). Niebuhr inveighed against American exceptionalism, the notion that the United States was morally pure, and the idea that "a good cause will hallow any weapon," cautioning against "too great confidence in our virtue" (Niebuhr 1952, pp. 40,42). He was deeply skeptical of technological solutions to human problems, warning that

the degree of American power tends to generate illusions to which a technocratic culture is already too prone. This technocratic approach to problems of history, which erroneously equates the mastery of nature with the mastery of historical destiny, in turn accentuates a very old failing in human nature: the inclination of the wise, or the powerful, or the virtuous, to obscure and deny the human limitations in all human achievements and pretensions.

(Niebuhr 1952, p. 147)

These comments, published in 1952, mark Niebuhr as less a just war thinker than an incipient nuclear pacifist. The central elements of his analysis run contrary to the views of the just war thinkers, who placed great faith in both American power and advances in nuclear weapons and related technologies (e.g., strategic defenses). Equally, they anticipate and provide a kind of 
confirmation-in-advance of the views of the nuclear pacifists within the U.S. Catholic and Mainline Protestant Churches.

\section{The Impact on U.S. Policy}

Did the views of, and the debate between, the just war thinkers and the nuclear pacifists exert any influence on U.S. policy? As noted above, the development of U.S. nuclear strategy during the Cold War was remarkably consistent with Ramsey's views. According to Yoder, "many hold that he and his [fellow just war thinkers] contributed" to the evolution of Pentagon policy away from massive retaliation to "graduated" or "flexible response." (Yoder 2009, p. 338). This is not an unreasonable conclusion. The early Cold War was an era in which Christian (especially Protestant) ethicists and theologians were taken seriously within both government and the broader society. Partly as a result, the debates among nuclear strategists and policymakers on the one hand, and those among theologians and ethicists on the other, were not conducted in isolation from one another. Ramsey's writings are replete with references to such nuclear strategists as Thomas Schelling and Herman Kahn. Like others of the time, he was familiar with and engaged directly with these strategists and their arguments-and they with him.

At the same time, direct, concrete evidence for the influence on U.S. policy of Ramsey and other just war thinkers is generally lacking. There is virtually no mention of them in the scholarly works or memoirs of nuclear theorists and governmental officials such as Henry Kissinger or Robert McNamara. Indeed, when "McNamara was asked in 1985 if he could recall any religious or ethical writing that had influenced him as secretary of defense, he candidly answered no" (Boyer 2012, p. 188). According to Joseph Nye, who served in multiple State and Defense Department posts, "The moralists formulate fine principles that seem to the strategists about as relevant to a foreign policy as a belief in the tooth fairy is to the practice of dentistry" (Nye 1986, p. 11). Even a cursory reading of scholarly writings and government documents reveals that practical (realist) considerations, especially the credibility of the U.S. nuclear deterrent, weighed much more heavily than ethical or religious considerations on the minds of nuclear strategists. The arguments of the just war thinkers were welcomed in the defense community because they were consistent both with the Defense Department's preferred nuclear strategy and with the Pentagon's organizational interests (e.g., more weapons, larger budgets). And they were useful as a means of gaining public approval in a country that views itself as exceptional and that has typically sought to justify its policy decisions in moral terms. But there is insufficient evidence to conclude that the moral arguments of Murray, Ramsey, and other just war theorists were a motivating force behind evolving U.S. strategic doctrine.

And what of the eventual triumph of nuclear pacifism in many U.S. churches? What was its impact? From a political perspective, the U.S. Catholic and Mainline Protestant Churches offered, to some, a compelling alternative to the views that prevailed among the just war thinkers and the "nuclear priesthood" of strategists within the policy making community and academia. The latter were thus forced to recognize the arguments of the nuclear pacifists and respond publicly to them. To cite just one example: In the June 1983, issue of Commentary, Albert Wohlstetter, a well-known strategist and senior fellow at the conservative Hoover Institution, published an essay, "Bishops, Statesmen, and Other Strategists on the Bombing of Innocents," in which he offered a pointed critique of the U.S. Catholic Bishops' pastoral letter of earlier that year. Countering the Bishops was necessary, wrote Wohlstetter, because their "moral prestige alone" gave them influence over Catholics and non-Catholics alike. Their views, he continued, "reinforce the impassioned pacifist and neutralist movements that have been growing in Europe and in the United States" (Wohlstetter 1983, p. 16).

The effect on public opinion of the churches' pronouncements is difficult to disentangle from the impact of broader events and trends in U.S. society, some of which have been discussed above. But they clearly had an impact. An analysis of survey data published by Daniel Yankelovich and John Doble in 1984 showed that nuclear pacifist views resonated deeply with the U.S. public. Eighty-nine percent of Americans, they found, believed that "there can be no winner in an all-out nuclear 
war." Eighty-three percent believed that "there can be no such thing as a limited nuclear war; if either side were to use nuclear weapons, the conflict would inevitably escalate into all-out nuclear war." The authors concluded, "The American electorate wants to reverse the present trend toward relying ever more heavily on nuclear weapons to achieve the nation's political and military objectives. The public finds the long-term risks of continuing the way we are going to be simply unacceptable" (Yankelovich and Doble 1984, pp. 33, 37, 46).

Despite this, the long-term impact on U.S. policy of the triumph of nuclear pacifism within the U.S. Catholic Church and Mainline Protestant denominations during the 1980s appears to have been modest at best. Nuclear deterrence remains the foundation of U.S. national security policy. U.S. strategic doctrine still relies heavily on counter-force targeting, while maintaining a strong countervalue capability. Just war theory (the law of war)—not nuclear pacifism-is taught in the U.S. service academies. Most importantly, although the United States and Russia reduced the size of their nuclear arsenals in the aftermath of the Cold War's end, there has in recent years been no real movement on either side in the direction of nuclear disarmament.

There are many reasons for this, including the end of the Cold War, which diminished the sense of urgency felt by nuclear pacifists, technological momentum, the rise of new nuclear threats such as North Korea, and the institutional interests of defense organizations on both sides. In the United States, the influence of Mainline Protestantism has waned, while that of Evangelical Protestantism has grown by leaps and bounds. Although not heavily involved in the debate between the just war thinkers and the nuclear pacifists for much of the Cold War, Evangelical Protestants (aside from the Mennonites and the Church of the Brethren) tend to be considerably more "hawkish" on national security issues than their Mainline Protestant or Catholic counterparts. In 1986, during the period in which Mainline Protestant churches and the U.S. Catholic Bishops were issuing their manifestoes, the National Association of Evangelicals produced a set of guidelines, Peace, Freedom, and Security Studies. While this document was more tentative and less declaratory than the others and did not address U.S. strategic doctrine and weapons systems in much detail, it did express support for "the shift to defensive weapons" advocated by the Reagan Administration. The guidelines acknowledged that SDI "could lead to a massive expansion of arm[s] expenditures." But, the NAE argued,

It could also provide the occasion for new efforts at mutual security arrangements-action to protect people of the U.S. and the Soviet Union from nuclear attack. America could take the lead in bringing such security arrangements into being, not simply for us and for our adversaries, but for a world now dominated by the threat of nuclear war. Such efforts, when allied to the pursuit of the other goals listed here, could lead to conditions in which major cuts in all forms of military expenditures become feasible. (National Association of Evangelicals NAE)

The increasing importance of Evangelical Protestants in U.S. society and their emergent role as the electoral base of the Republican Party provided, during the Reagan Administration and after, a substantial counterweight to the nuclear pacifism advocated by the U.S. Catholic and Mainline Protestant churches. It thus helps to explain the minimal long-term implications of nuclear pacifism for U.S. policy.

Acknowledgments: The author wishes to thank Jay Corrin, John Zawacki, and two anonymous reviewers for their comments and suggestions on an earlier version of this essay.

Conflicts of Interest: The author declares no conflicts of interest.

\section{References}

Au, William A. 1985. The Cross, the Flag, and the Bomb: American Catholics Debate War and Peace, 1960-1983. Westport: Greenwood Press. 
Boffey, Philip M. 1985. Dark Side of 'Star Wars': System Could Also Attack. New York Times. March 7. Available online: https:/ / www.nytimes.com/1985/03/07/world/dark-side-of-star-wars-system-could-also-attack. html (accessed on 21 February 2018).

Boyer, Paul. 1984. From Activism to Apathy: The American People and Nuclear Weapons, 1963-1980. Journal of American History 70: 821-44. [CrossRef]

Boyer, Paul. 2012. God, the Bomb, and the Cold War: The Religious and Ethical Debate Over Nuclear Weapons, 1945-1990. In Uncertain Empire: American History and the Idea of the Cold War. Edited by Joel Isaac and Duncan Bell. Oxford: Oxford University Press, pp. 165-94.

Castelli, Jim. 1983. The Bishops and the Bomb: Waging Peace in a Nuclear Age. Garden City: Image Books.

Davidson, Donald L. 1983. Nuclear Weapons and the American Churches: Ethical Positions on Modern Warfare. Prepared under the auspices of the Strategic Studies Institute. U.S. Army War College. Boulder: Westview Press.

Downes, Alexander B. 2008. Targeting Civilians in War. Cornell Studies in Security Affairs. Ithaca: Cornell University Press.

Episcopal Church. Diocese of Washington, Commission on Peace. 1987. The Nuclear Dilemma: A Christian Search for Understanding. A Report of the Committee of Inquiry on the Nuclear Issue, Commission on Peace, Episcopal Diocese of Washington. Cincinnati: Forward Movement Publications.

Federal Council of Churches (FCC). 1946. Atomic Warfare and the Christian Faith. Report of the Commission on the Relation of the Church to the War in Light of the Christian Faith to the Federal Council of the Churches of Christ in America. Columbus: Federal Council of Churches.

Francis, Matthew R. 2017. When Carl Sagan Warned the World about Nuclear Winter. Smithsonian.com. Available online: https:/ /www.smithsonianmag.com/science-nature/when-carl-sagan-warned-worldabout-nuclear-winter-180967198/ (accessed on 6 March 2018).

Halloran, Richard. 1982. Pentagon Draws Up First Strategy for Fighting a Long Nuclear War. New York Times. May 30. Available online: https:/ / www.nytimes.com/1982/05/30/world/pentagon-draws-up-first-strategyfor-fighting-a-long-nuclear-war.html (accessed on 9 March 2018).

Lackey, Douglas P. 1984. Moral Principles and Nuclear Weapons. Totowa: Rowman and Allanheld.

McBrady, Jared. 2015. The Challenge of Peace: Ronald Reagan, John Paul II, and the American Bishops. Journal of Cold War Studies 17: 129-52. Available online: https:/ / muse.jhu.edu/article/581233 (accessed on 15 March 2018). [CrossRef]

Murray, John Courtney. 1960. We Hold These Truths: Catholic Reflections on the American Proposition. New York: Sheed and Ward.

National Association of Evangelicals (NAE). 1986. Peace, Freedom, and Security Studies. Available online: https: / /www.nae.net/530/ (accessed on 20 February 2018).

National Conference of Catholic Bishops (NCCB). 1983. The Challenge of Peace: God's Promise and Our Response. A Pastoral Letter on War and Peace. Washington: United States Catholic Conference.

Niebuhr, Reinhold. 1940. Why the Christian Church is Not Pacifist. In Niebuhr, Christianity and Power Politics. New York: Charles Scribner's Sons.

Niebuhr, Reinhold. 1952. The Irony of American History. New York: Charles Scribner's Sons.

Niebuhr, Reinhold. 1953. Christian Realism and Political Problems. New York: Scribner.

Nye, Joseph S., Jr. 1986. Nuclear Ethics. New York: Free Press.

O'Brien, William V. 1984. The Just War Theory: A Christian Realist Perspective. Edited by Jean Bethke Elshtain. New York: New York University Press, pp. 169-96.

Pavlischek, Keith. 2008. Reinhold Niebuhr, Christian Realism, and Just War Theory: A Critique. In Christianity and Power Politics Today. Edited by Eric Patterson. New York: Palgrave Macmillan, pp. 53-71.

Presbyterian Church (USA). 1988. Christian Obedience in a Nuclear Age. Available online: http:/ / www.pcusa. org/resource/christian-obedience-nuclear/ (accessed on 16 February 2018).

Pope John, XXIII. 1963. Pacem in Terris. An Encyclical of Pope John XXIII on Establishing Universal Peace in Truth, Justice, Charity, and Liberty. Available online: http:/ /w2.vatican.va/content/john-xxiii/en/encyclicals / documents/hf_j-xxiii_enc_11041963_pacem.html (accessed on 16 February 2018).

Pope Paul, VI. 1965. Gaudium et Spes. Pastoral Constitution on the Church in the Modern World. Available online: http://www.vatican.va/archive/hist_councils/ii_vatican_council/documents/vat-ii_ const_19651207_gaudium-et-spes_en.html (accessed on 22 February 2018). 
Ramsey, Paul. 1961. War and the Christian Conscience: How Shall Modern War be Conducted Justly? Durham: Duke University Press.

Ramsey, Paul. 1963. The Limits of Nuclear War: Thinking about the Do-able and the Un-do-able. New York: The Council on Religion and International Affairs.

Ramsey, Paul. 1968. The Just War: Force and Political Responsibility. New York: University Press of America.

Ramsey, Paul. 1988. Speak Up for Just War or Pacifism: A Critique of the United Methodist Bishops' Pastoral Letter "In Defense of Creation". Epilogue by Stanley Hauerwas. University Park: Pennsylvania State University Press.

Reagan, Ronald. 1983a. Address to the Nation on Defense and National Security. Available online: https:/ / www. reaganlibrary.gov/sites/default/files/archives/speeches/1983/32383d.htm (accessed on 27 February 2018).

Reagan, Ronald. 1983b. Evil Empire Speech. Voices of Democracy: The U.S. Oratory Project. Available online: http:/ / voicesofdemocracy.umd.edu/reagan-evil-empire-speech-text/ (accessed on 27 February 2018).

Sagan, Scott D., and Benjamin A. Valentino. 2017. Revisiting Hiroshima in Iran: What Americans Really Think About Using Nuclear Weapons and Killing Noncombatants. International Security 42: 41-79. Available online: doi.org/10.1162/ISEC_a_00284 (accessed on 27 February 2018).

Slocombe, Walter. 1981. The Countervailing Strategy. International Security 5: 18-27. [CrossRef]

Stuever, Hank. 2016. Yes, 'The Day After' Really Was the Profound TV Moment 'The Americans' Makes It Out to Be. Washington Post. May 11. Available online: https://www.washingtonpost.com/news/arts-andentertainment/wp/2016/05/11/yes-the-day-after-really-was-the-profound-tv-moment-the-americansmakes-it-out-to-be/?utm_term=.0490dadbdc90 (accessed on 8 March 2018).

United Church of Christ (UCC). 1985. Pronouncement on Affirming the United Church of Christ as a Just Peace Church. Available online: http:/ / www.ucc.org/beliefs_theology_general-synod-pronouncement (accessed on 20 February 2018).

United Methodist Church (UMC). Council of Bishops. 1986. In Defense of Creation: The Nuclear Crisis and a Just Peace. Foundation Document. Nashville: Graded Press.

Van Kirk, Walter William. 1954. International Affairs-Christians in the Struggle for World Community. Ecumenical Review 7: 42-48. [CrossRef]

Weigel, George. 1987. Tranquillitas Ordinis: The Present Failure and Future Promise of American Catholic Thought on War and Peace. New York: Oxford University Press.

Wohlstetter, Albert. 1983. Bishops, Statesmen, and Other Strategists on the Bombing of Innocents. Commentary 75: 15-35.

Yankelovich, Daniel, and John Doble. 1984. The Public Mood: Nuclear Weapons and the U.S.S.R. Foreign Affairs 63: 33-46. [CrossRef]

Yoder, John Howard. 2009. Christian Attitudes to War, Peace, and Revolution. Edited by Theodore J. Koontz and Andy Alexis-Baker. Grand Rapids: Brazos Press. 